\title{
An automated microbiological method for the measurement of vitamin $\mathrm{B}_{12}$
}

\author{
R. E. DAVIS, J. MOULTON, AND A. KELLY \\ From the Department of Haematology, Royal Perth Hospital, Western Australia
}

SYNOPSIS An automated method for the microbiological assay of vitamin $B_{12}$ is described. A chloramphenicol-resistant strain of Lactobacillus leichmannii is used as the test organism and this eliminates the need for sterilization or aseptic addition. Precipitation of the serum protein is avoided by dilution of the serum with a glutamic/malic acid solution before heating the preparation to free the vitamin $B_{12}$. Tests can be set up at a rate of 80 an hour and after incubation they can be read at 160 an hour. By interfacing a programmed electronic calculator directly with the Mecolab $\mathrm{M}$ which is used for the assays, results are printed directly in $\mathrm{ng} / \mathrm{l}$.

The microbiological assay of vitamin $B_{12}$ in serum was first described by Ross (1950) more than 20 years ago using Euglena gracilis var. bacillaris as the test organism. The technique was tedious and time consuming and required elaborate procedures for the cleaning of glassware. Later the $\mathrm{Z}$ strain of Euglena gracilis was introduced and this shortened the growth period required for the assay to five days (Hutner, Bach, and Ross, 1956). This technique gave highly reproducible results and appeared specific for vitamin $B_{12}$ in serum. Spray (1955) described a rapid assay technique using Lactobacillus leichmannii as the test organism, the method gave rather higher results than were obtained using Euglena and was not as specific but had the advantage of being able to provide a result in 24 hours. Variations of this basic method are used by many laboratories. In 1965 Lau, Gottlieb, Wasserman, and Herbert described an assay technique based on isotope dilution. This technique is useful for laboratories making a limited number of measurements, but it has not been used where very large numbers of samples require measurement, and more recently doubts have been cast on the validity of some of the results (Raven, Robson, Morgan, and Hoffbrand, 1972).

We describe here a fully automated method for the microbiological measurement of vitamin $B_{12}$ using Lactobacillus leichmanni as the test organism. Results are available in $\mathbf{2 4}$ hours and the equipment can set up tests at a speed of 80 an hour and can read results following incubation at 160 an hour.

Received for publication 22 May 1973.

\section{Materials and Methods}

A chloramphenicol-resistant strain of L. leichmanni was developed from the standard strain (ATCC 7830 NCIB 8117) by a method similar to that described by Davis, Nicol, and Kelly (1970) for Lactobacillus casei. The standard strain of the organism was passaged through liquid media containing increasing concentrations of chloramphenicol. A stock solution of $0.1 \%$ chloramphenicol base in $1 \%$ ethanol was prepared. Increasing concentrations of the antibiotic were added to one ounce screw-capped bottles containing $10 \mathrm{ml}$ of single strength assa $y$ media with added vitamin $B_{12}(50 \mathrm{ng} / \mathrm{l})$. Each concentration was prepared in duplicate and chloramphenicol was added in the following increments: by $0.5 \mathrm{mg}$ steps from 1 to $10 \mathrm{mg} / \mathrm{l}$; then in $1.0 \mathrm{mg}$ steps to $20 \mathrm{mg} / \mathrm{l}$; $5 \mathrm{mg}$ steps to $100 \mathrm{mg} / \mathrm{l}$; and thereafter $10 \mathrm{mg}$ steps to $300 \mathrm{mg} / \mathrm{l}$. In the event of poor growth at any stage the organism was subcultured back into the previous concentration and incubated until satisfactory growth was achieved. The organism was suitable for use in $\underset{\omega}{\mathrm{\omega}}$ the assay when tolerant to a chloramphenicol 0 concentration of $200 \mathrm{mg} / \mathrm{l}$. In the assay proper 6 chloramphenicol was used at a concentration of 10 $\mathrm{mg} / \mathrm{l}$. The differential between the two concentrations of antibiotic was necessary to ensure vigorous growth of the test organism.

PRESERVATION OF THE TEST ORGANISM

The chloramphenicol-resistant organism was grown in maintenance media without chloramphenicol until a heavy growth was obtained; this usually took 24-36 
hours. The culture was then centrifuged and the supernatant discarded. Five per cent sodium glutamate was added to give a heavy suspension of the organism. A few drops of this suspension were then added to an ampoule containing about 100 small sterile ceramic beads. The ampoule was gently shaken to coat the beads with the organism, it was then connected to a vacuum system and the organisms dried from the liquid phase. The dried organisms were stored in a screw-capped bottle to which two crystals of indicator silica gel had been added. The method was essentially that described by Annear (1962).

\section{PREPARATION OF INOCULUM}

On the day before the test a tube containing $10 \mathrm{ml}$ of maintenance media was inoculated with one ceramic bead containing the dried organism. The use of assay media with added vitamin $B_{12}$ for the preparation of the inoculum rather than less well defined media such as broth had the advantage of promoting the growth of the test organisms under conditions similar to those found in the test proper. The culture was incubated overnight at $37^{\circ} \mathrm{C}$ after which it was centrifuged and the supernatant discarded. The organisms were suspended in saline to give an optical density of 1.0 . To each litre of double-strength assay medium $2.0 \mathrm{ml}$ of this suspension was added immediately before the test.

\section{SUBSTRATE}

Double-strength assay medium was prepared according to the protocol in table I. After mixing the $\mathrm{pH}$ was adjusted to 6.9 , the medium was then stored at $-20^{\circ} \mathrm{C}$ in 2-litre plastic containers. It will keep under these conditions for many months. Alternatively Difco $B_{12}$ assay medium USP may be used provided the $\mathrm{pH}$ is first adjusted to 6.9 . Immediately before use chloramphenicol was added to a concentration of $20 \mathrm{mg} / \mathrm{l}$.
MAINTENANCE MEDIUM

This was single-strength assay medium containing $50 \mathrm{ng} / 1$ of vitamin $B_{12}$ and $100 \mathrm{mg} / \mathrm{l}$ chloramphenicol.

\section{DISASSOCIATING VITAMIN B B $_{12}$ FOM ITS CARRIER}

Most of the vitamin $B_{12}$ present in serum is bound to a protein transcobalamin and is not available to the test organism in this form. The vitamin is usually freed from the protein carrier with the aid of heat; this also results in precipitation of the serum proteins unless the preparation has a low $\mathrm{pH}$. When using $E$. gracilis as the test organism precipitation of the serum proteins does not occur because the $\mathrm{pH}$ of the preparation is $3 \cdot 6$, whereas assays using $L$. leichmannii are run at a $\mathrm{pH}$ of 5.9 and heating will precipitate the proteins. To overcome this problem serum samples were diluted into $2.45 \mathrm{ml}$ of a solution containing $0.2 \mathrm{~g}$ of malic acid and $3.0 \mathrm{~g}$ of glutamic acid per litre; the pH of this solution should be $3 \cdot 6$. The tubes were then placed in a water bath at $100^{\circ} \mathrm{C}$ for five minutes after which they were cooled and processing continued. The optimum heating time was determined by placing an acidified sample in a boiling water bath and removing aliquots at one-minute intervals. No increase in free vitamin $B_{12}$ occurred after three minutes' heating.

\section{ST A NDARDS}

A stock solution was prepared by dissolving $10 \mathrm{mg}$ of crystalline cyanocobalamin (Sigma) in $500 \mathrm{ml}$ of distilled water to give a concentration of $20 \mathrm{mg} / \mathrm{l}$. One millilitre of this solution was then diluted to $100 \mathrm{ml}$ with distilled water to give a concentration of 200 $\mu \mathrm{g} / \mathrm{l}$. A working solution was prepared by taking $1 \mathrm{ml}$ of the last dilution and again diluting to $200 \mathrm{ml}$ with distilled water. The working solution may be kept for four weeks when stored at $4^{\circ} \mathrm{C}$; the stock solution will keep for months if refrigerated. The working

\begin{tabular}{|c|c|c|c|}
\hline 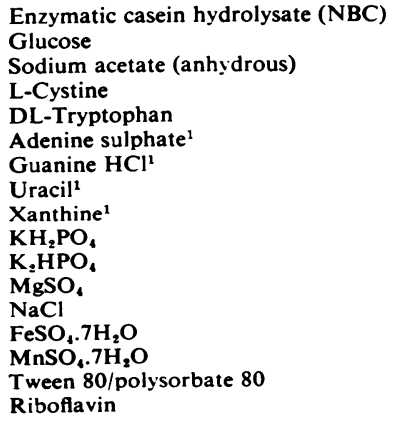 & $\begin{array}{l}200 \mathrm{ml} \\
40 \mathrm{~g} \\
12 \mathrm{~g} \\
200 \mathrm{mg} \\
400 \mathrm{mg} \\
10 \mathrm{mg} \\
10 \mathrm{mg} \\
10 \mathrm{mg} \\
10 \mathrm{mg} \\
1 \mathrm{~g} \\
1 \mathrm{~g} \\
400 \mathrm{mg} \\
20 \mathrm{mg} \\
20 \mathrm{mg} \\
20 \mathrm{mg} \\
2 \mathrm{~g} \\
2 \mathrm{mg}\end{array}$ & $\begin{array}{l}\text { Ca pantothenate } \\
\text { Pyridoxine } \mathrm{HCl} \\
\text { Thiamine } \mathrm{HCl} \\
\text { Nictoninic acid } \\
\text { Biotin } \\
\text { Folic acid } \\
\text { Pyridoxal } \\
\text { p-Amino benzoic acid } \\
\text { DL-a-alanine } \\
\text { Thiomalic acid } \\
\text { CaCl, } \\
\text { Guanosine } \\
\text { Guanylic acid } \\
\text { Cysteine } \\
\text { Glutamine } \\
\text { Distilled water to }\end{array}$ & $\begin{array}{r}2 \mathrm{mg} \\
4 \mathrm{mg} \\
4 \mathrm{mg} \\
2 \mathrm{mg} \\
10 \mathrm{\mu g} \\
1 \mathrm{mg} \\
1 \mathrm{mg} \\
1 \mathrm{mg} \\
1 \mathrm{~g} \\
1 \mathrm{~g} \\
200 \mathrm{mg} \\
200 \mathrm{mg} \\
200 \mathrm{mg} \\
1 \mathrm{~g} \\
400 \mathrm{mg} \\
1 \mathrm{litre}\end{array}$ \\
\hline
\end{tabular}

Table I Double-strength assay medium

Dissolved by suspending in a small volume of $\mathrm{H}_{2} \mathrm{O}$ and then adding concentrated $\mathrm{KOH}$ drop by drop until solution is complete. 


\begin{tabular}{|c|c|c|c|c|}
\hline $\begin{array}{l}\text { Standard Tube } \\
\text { Number }\end{array}$ & $\begin{array}{l}\text { Volume of Working } \\
\text { Solution }\end{array}$ & $\begin{array}{l}\text { Volume } \\
\text { of } \mathrm{H}_{2} \mathrm{O}\end{array}$ & $\begin{array}{l}\text { Concentration } \\
\text { in } \mathrm{ng} / \mathrm{l}\end{array}$ & $\begin{array}{l}\text { Concentration in ng/l after Dilution with } \\
\text { Substrate }\end{array}$ \\
\hline 0 & 0 & 4.0 & 0 & 0 \\
\hline 1 & 0.4 & 3.6 & 100 & 1.0 \\
\hline 2 & 0.6 & 3.4 & 150 & $1 \cdot 5$ \\
\hline 3 & 0.8 & $3 \cdot 2$ & 200 & $2 \cdot 0$ \\
\hline 4 & 1.0 & 3.0 & 250 & $2 \cdot 5$ \\
\hline 5 & $1 \cdot 2$ & $2 \cdot 8$ & 300 & 3.0 \\
\hline 6 & $1 \cdot 6$ & $2 \cdot 4$ & 400 & $4 \cdot 0$ \\
\hline 7 & $2 \cdot 0$ & $2 \cdot 0$ & 500 & $5 \cdot 0$ \\
\hline 8 & $2 \cdot 4$ & 1.6 & 600 & 6.0 \\
\hline 9 & $3 \cdot 2$ & 0.8 & 800 & $8 \cdot 0$ \\
\hline 10 & $4 \cdot 0$ & 0 & 1000 & $10 \cdot 0$ \\
\hline
\end{tabular}

Table II Preparation of working solutions for standard curve

solution was used to prepare the final standard solutions as shown in the protocol (table II) and these were sampled in the same manner as the serum or other material to be assayed.

\section{ASSAY PROCEDURE}

The method was designed to use a specifically modified version of the Joyce Loebl automated chemistry apparatus, Mecolab $M$ (fig. 1). This unit provides the following automated facilitiessample dilution, reagent addition, mixing of bacterial growth after incubation, measurement, and digital estimation of bacterial growth.

A diluter on the universal sampler unit was adjusted to sample $0.05 \mathrm{ml}$ of serum and to dilute this with $2.45 \mathrm{ml}$ of malic/glutamic acid solution. The sampler holds $\mathbf{4 0}$ serum samples and $\mathbf{4 0}$ assay tubes in circular racks. The machine was programmed to sample each serum and deliver it with $2.45 \mathrm{ml}$ of malic/glutamic acid solution into a plastic disposable $-v$ assay tube. When this has been completed the machine stops automatically. Racks of assay tubes ${ }^{+}$ were removed and placed in a water bath at $100^{\circ} \mathrm{C}$ 은 for five minutes, allowed to cool, then returned to the turntable.

Double-strength assay medium was inoculated with the test organism as described earlier and the $\overrightarrow{0}$ flask placed on a magnetic stirrer on top of the $\omega$ sampler unit. A diluter was used to deliver $2.5 \mathrm{ml}$ of the inoculated medium into each of the tubes giving a final dilution of 1 in 100 . Standards were treated in the same manner as the serum samples. They were set up in triplicate with two extra blanks and two $\stackrel{\varnothing}{\complement}$ extra top standards. After setting up, racks of tubes $\overrightarrow{\vec{A}}$ were incubated at $37^{\circ} \mathrm{C}$ for approximately 24 hours 3 or until the top standard reached an optical density

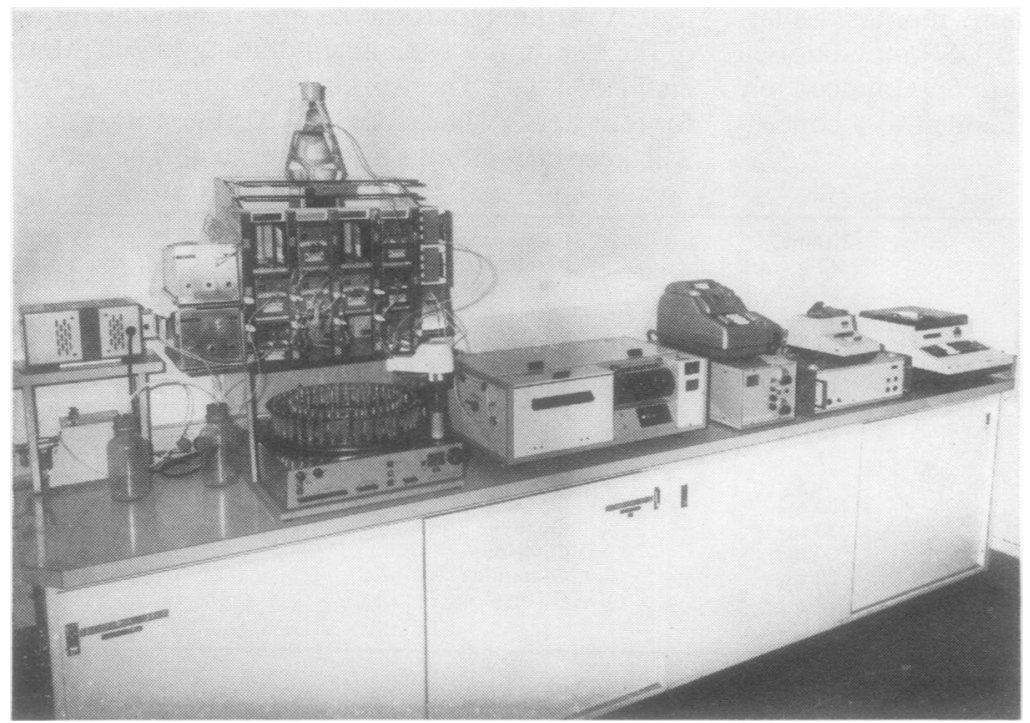

Fig 1 Mecolab $M$ showing from left to right sample preparation unit, autocolorimeter, $A / D$ converter and printer, interfaced calculator with tape reader for insertion of programs. 
of $0 \cdot 33$. The racks were then returned to the Mecolab where the contents of each tube were mixed and the growth measured in the colorimeter. Results were recorded in digital form onto paper tape.

\section{CALCULATION OF RESULTS}

Readings obtained from the standards can be used to plot a curve on linear graph paper, and the concentration of the unknown can be determined by interpolation. However, this is inconvenient when large numbers of samples are being processed. A more satisfactory approach is to use a programmable electronic calculator such as the Diehl Combitron $\mathrm{S}$ with punch tape reader. The program can be punched onto paper tape and by passing this through the tape reader the machine can be rapidly set up.

The Combitron $\mathrm{S}$ uses the following formula for linear interpolation:

$$
y=\mathrm{d}-\frac{(\mathrm{d}-\mathrm{b})(\mathrm{c}-x)}{(\mathrm{c}-\mathrm{a})}
$$

The formula assumes a straight line between any two points on the curve and this introduces a small degree of error which has not been found to exceed $2.5 \%$.

The program was fed into the punched tape reader and the absorbence values obtained from the standards were entered into the Diehl Combitron S where they were matched with the standard concentrations that they represent, ie, $100,200,300,600$, and $1000 \mathrm{ng} / \mathrm{l}$. The unknown values were then entered into the machine and a number of logical decisions were made to determine between which two points on the curve the unknown fitted. The machine then applied the linear interpolation formula using the appropriate values for $\mathrm{A}, \mathrm{C}, \mathrm{B}$, and $\mathrm{D}$, and the result is printed together with the original absorbence value onto paper tape.

$$
\begin{aligned}
& \text { Example (fig 2) } \\
& x=267 \\
& a=200 \\
& c=400 \\
& y=d-\frac{(d-b)(c-x)}{c-a} \\
& =600-\frac{(600-300)(400-267)}{400-200} \\
& =600-\frac{(300)(133)}{200} \\
& =600-199 \cdot 5 \\
& =400 \cdot 5 \mathrm{ng} / 1
\end{aligned}
$$

When using small calculators in this way the time

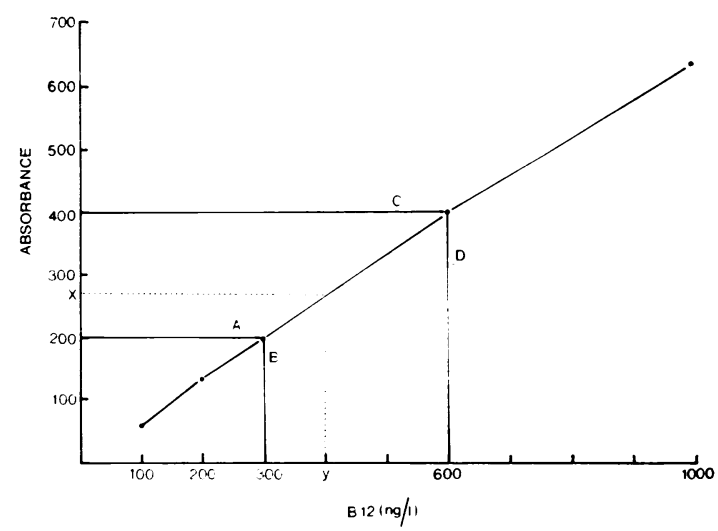

Fig 2 Point selection for linear interpolation.

taken for each calculation extends over several seconds and this must not be allowed to exceed the time taken by the Mecolab to measure sample absorbence. A maximum of 20 seconds is permitted and this restricts the number of standards that can be used.

The output of the Mecolab may be interfaced directly with the Combitron $S$; the calculator will then automatically print the absorbence value and the concentration in $\mathrm{ng} / \mathrm{l}$.

Vitamin $\mathbf{B}_{12}$ was also measured using Euglena gracilis as the test organism (Nicholas and Pitney, 1958). The normal range for this laboratory is 160 $875 \mathrm{ng} / \mathrm{l}$.

A total of 150 sera was assayed by both the automated $L$. leichmannii and $E$. gracilis methods. One hundred were from normal individuals and 50 were from patients with a variety of disorders which included vitamin $\mathbf{B}_{12}$ malabsorption and liver disease.

\section{Results}

The comparison between the L. leichmannii and $E$. gracilis assays are shown in fig 3 and the difference was statistically significant $(0.001<P<0.01)$. However, the difference was constant at all levels. Results using the present method if multiplied by a factor of 0.734 gave results similar to those obtained using Euglena and results using Euglena if multiplied by a factor of 1.3 gave results similar to those obtained with $L$. leichmannii; using these factors the correlation coefficient was 0.951 . The least significant difference using an analysis of duplicates with L. leichmannii was $108 \mathrm{ng} / \mathrm{l}$ with a coefficient of variation of $9.445 \%$; this was not quite as good as that obtained with the Euglena assay of $82.9 \mathrm{ng} / 1$ and a coefficient of 


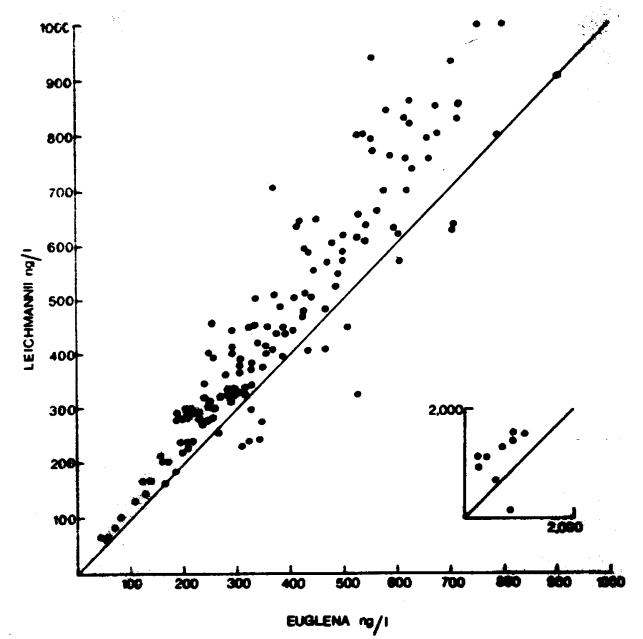

Fig 3 Comparison of vitamin $B_{12}$ values obtained from 150 sera by $\mathrm{E}$. gracilis and $\mathrm{L}$. leichmannii assays.

variation of $7.553 \%$. The mean of the 100 sera from normal individuals was $410 \mathrm{ng} / \mathrm{l}$ (range 150-1000 $\mathrm{ng} / \mathrm{l}$ ) when assayed using $L$. leichmannii. Ten serum samples had a low vitamin $B_{12}$ concentration when assayed using $L$. leichmannii as the test organism. The assay was repeated using $E$. gracilis as the test organism and the results are shown in table III.

A number of workers have recommended the addition of cyanide to the assay system (Girdwood,

\begin{tabular}{lc}
\hline $\begin{array}{l}\text { Euglena gracilis } \\
n g / l)\end{array}$ & $\begin{array}{c}\text { Lactobacillus leichmannii } \\
(\text { ng/l) }\end{array}$ \\
\hline$(36$ & 65 \\
50 & 60 \\
50 & 54 \\
72 & 100 \\
120 & 140 \\
60 & 80 \\
165 & 200 \\
130 & 165 \\
100 & 130 \\
180 & 180 \\
\hline
\end{tabular}

Table III Comparison of results obtained in 10 samples with low levels using Euglena gracilis and Lactobacillus leichmannii.

1960; Brandt and Metz, 1961; Spray, 1962; Matthews, 1962) since it has been suggested that $L$. leichmannii is only sensitive to cyanocobalamin. To determine the effect of cyanide on the assay 32 serum samples were assayed with and without the addition of sodium cyanide $(0.0125 \mathrm{~g} / \mathrm{l})$; the results showed no significant difference, $Z=0.02941$.

\section{Discussion}

A rapid, fully automated method suitable for the measurement of serum vitamin $B_{12}$ in serum has been described. The method uses a chloramphenicol- $\frac{}{\circ}$ resistant strain of $L$. leichmannii as the test organism $\frac{\bar{\sigma}}{\bar{s}}$ and this has removed the need for sterilization or $\overline{\mathbb{D}}$ aseptic addition.

Precipitation of serum protein has been overcome ${ }^{\infty}$ by the use of a malic/glutamic acid diluent before $\overrightarrow{0}$ heating the samples to free the vitamin from its $\vec{\overrightarrow{ }}$ protein carrier. When combined with an automated ${ }_{\sigma}$ folate assay system (Davis et al, 1970) a large number of samples can be processed and results from both assays are available within 24 hours.

The mean level for 100 sera was $\therefore 10 \mathrm{ng} / \mathrm{l}$ (range. $*$ 150-1000) compared with a mean of 471 (range $\frac{0}{+}$ $155-1075 \mathrm{ng} / \mathrm{l})$ reported by Raven and his colleagueso (1972). Although results are higher than those ${ }_{-}$ obtained with the Euglena assay the difference isc constant and adjusted results have a close corre $\stackrel{\frac{c}{<}}{ }$ lation.

The acid diluent is of low ionic strength and the $\mathrm{pH}$ of the assay medium is adjusted so that a final $\mathrm{pH}$ of 5.9 is achieved.

The method is particularly well suited for institutional and population surveys. Results below 200 ng/1 may be confirmed using the Euglena assay.

We wish to thank Mr D. J. Nicol for his help with $\overrightarrow{\vec{O}}$ the statistical analysis, and Dr J. M. Jackson for his 3 encouragement.

\section{References}

Annear, D. I. (1962). Recoveries of bacteria after drying on cellulose? fibres. Aust. J. exp. Biol. med. Sci., 40, 1-8.

Brandt, V., and Metz, J. (1961). Serum vitamin $\mathbf{B}_{12}$ levels in South. African white and Bantu subjects. $S$. Afr. J. med. Sci., 26, 1-3.

Davis, R. E., Nicol, D. J., and Kelly, A. (1970). An automated method음 for the meas urement of folate activity. J. clin. Path., 23, 47-53.?

Girdwood, R. H. (1960). Microbiological methods of assay in clinicalo medicine with particular reference to the investigation of deficiency of vitamin $\mathrm{B}_{12}$ and folic acid. Scot. med. J., 5, 10-22. D

Hutner, S. H., Bach, M. K., and Ross, G. I. M. (1956). A s'ugar-O containing basal medium for vitamin $\mathrm{B}_{12}$-assay with Euglena: application to body fluids. J. Protozool., 3, 101-112.

Lau, K-S., Gottlieb, C., Wasserman, L. R., and Herbert, V. (1965) Measurement of serum vitamin $B_{12}$ level using radioisotope $N$ dilution and coated charcoal. Blood, 26, 202-214.

Matthews, D. M. (1962). Observations on the estimation of serum vitamin $B_{12}$ using Lactobacillus leichmannii. Clin. Sci., 22, $101-111$.

Nicholas, Deirdre R., and Pitney, W. R. (1958). Microbiological assaxe of vitamin $\mathrm{B}_{12}$ content of serum using Euglena gracilis. Aust. J. exp. Biol. med. Sci., 36, 603-608.

Raven, J. L., Robson, M. B., Morgan, J. O., and Hoffbrand, A. V. (1972). Comparison of three methods for measuring vitamin $\square$ $\mathbf{B}_{12}$ in serum: radioisotopic, Euglena gracilis and Lactobacillus $\bar{O}$ leichmannii. Brit. J. Haemat., 22, 21-31.

Ross, G. I. M. (1950). Vitamin $\mathbf{B}_{12}$ assay in body fluids. Nature (Lond.), 166, 270-271.

Spray, G. H. (1955). An improved method for the rapid estimation of vitamin $B_{12}$ in serum. Clin. Sci., 14, 661-667.

Spray, G. H. (1962). The estimation of significance of the level of vitamin $\mathrm{B}_{12}$ in serum. Postgrad. med. J., 38, 35-40. 